\title{
PENDAMPINGAN PENYUSUNAN RANCANGAN PERATURAN DESA TENTANG PENCEGAHAN DAN PENANGANAN STUNTING DI DESA GELOGOR KECAMATAN KEDIRI KABUPATEN LOMBOK BARAT
}

\author{
Imawanto'), Lelisari1), Nurjannah S.1) \\ 1)Fakultas Hukum Universitas Muhammadiyah Mataram, Mataram, NTB, Indonesia \\ Corresponding author: Lelisari \\ Email: slelisari@gmail.com
}

Diterima 29 November 2021, Direvisi 10 Desember 2021, Disetujui 10 Desember 2021

\begin{abstract}
ABSTRAK
Angka stunting di Nusa Tenggara Barat (NTB) masih terbilang tinggi yaitu sekitar 167 ribu atau 33,49 persen dari 500 ribu balita mengalami stunting. Hasil Riset Kesehatan Dasar Kabupaten Lombok Barat Tahun 2018 untuk balita usia 0-59 bulan menunjukkan bahwa indeks berat badan menurut umur (BB/U) angka kurang gizi sebesar $29.94 \%$, yang artinya bahwa Kabupaten Lombok Barat berada pada kategori wilayah rawan gizi. Penanganan masalah stunting tidak mungkin bisa diselesaikan sendiri oleh sektor kesehatan, oleh sebab itu perlu dukungan seluruh jajaran perangkat daerah dan masyarakat. Seperti yang sudah dilakukan oleh Pemeritah Kabupaten Lombok Barat dengan membuat Peraturan Bupati Lombok Barat No 19.A Tahun 2020 tentang Pencegahan dan Penangan Stunting, diundangkan pada tanggal 17 April 2020 pada Berita Daerah Kabupaten Lombok Barat Tahun 2020 Nomor 19.A. Dimana, dalam Pasal 10 angka 14 (a) Peraturan Bupati Lombok Barat No 19.A Tahun 2020. menyatakan adanya peran perangkat daerah dalam aksi konvergensi stunting yaitu: Peran Pemerintah Desa ialah menetapkan peraturan desa tentang pencegahan dan penanganan stunting. Dalam hal ini Desa Gelogor Kecamatan Kediri Kabupaten Lombok Barat belum juga mempunyai peraturan desa tentang pencegahan dan penanganan stunting sesuai amanat dari Peraturan Bupati Lombok Barat No 19.A Tahun 2020.Berdasarkan data dan informasi yang diperoleh pada saat kegiatan penyusunan rencana pembangunan jangka menengah desa (RPJMDes) ada berbagai persoalan dan masalah yang dihadapi masyarakat terutama masyarakat miskin dan perempuan. Dari berbagai persoalan dan masalah yang ada dapat dirangkum salah satunya adalah penanganan masalah stunting. Kegiatan pengabdian ini bertujuan memberikan pendampingan penyusunan rancangan peraturan desa tentang pencegahan dan penanangan stunting. Adapun yang hadir pada kegiatan ini adalah Anggota Pemerintah Desa, BPD, perwakilan Kepala Dusun, kader Posyandu, BKKBN/Penyuluh KB Lombok Barat, remaja, ibu hamil dan ibu menyusui. Hasil dari kegiatan ini adalah Pemerintah Desa Gelogor saat ini sudah mempunyai draf rancangan peraturan desa. Dimana draf rancangan peraturan desa tersebut akan dibahas pada tahap selanjutnya oleh Pemerintah Desa, BPD dan stakeholder lainnya.
\end{abstract}

Kata kunci : stunting; rancangan; peraturan desa.

\begin{abstract}
The stunting rate in West Nusa Tenggara (NTB) is still relatively high, around 167,000 or 33.49 percent of the 500 thousand toddlers experiencing stunting. The 2018 West Lombok Regency Basic Health Research results for toddlers aged 0-59 months show that the bodyweight index for age $(\mathrm{W} / \mathrm{U})$ has a malnutrition rate of $29.94 \%$, which means that West Lombok Regency is in the category of nutritionally vulnerable areas. The health sector can't solve the stunting problem alone. Therefore it requires the support of all regional apparatus and the community as done by the Government of West Lombok Regency by making West Lombok Regent Regulation No. 19. A of 2020 concerning Prevention and Handling of Stunting, promulgated on April 17, 2020, in the Regional News of West Lombok Regency of 2020 Number 19. A. Where, in Article 10 number 14 (a) West Lombok Regent Regulation No. 19.An of 2020. states the role of regional apparatus in stunting convergence action, namely: The part of the Village Government is to stipulate village regulations regarding stunting prevention and handling. In this case, Gelogor Village, Kediri District, West Lombok Regency does not yet have a village regulation regarding stunting prevention and handling as mandated by the West Lombok Regent Regulation No. 19.An of 2020. Based on data and information obtained during the village medium-term development plan ( RPJMDes), the community faces various problems, especially
\end{abstract}


the poor and women. Of the various issues and problems that exist, it can be summarized, one of which is handling the stunting problem. This service activity aims to draft village regulations regarding stunting prevention and management. Those who attended this activity were Village Government Members, BPD, representatives of the Hamlet Head, Posyandu cadres, BKKBN / West Lombok Family Planning Extension, teenagers, pregnant women, and breastfeeding mothers. The result of this activity is that the Gelogor Village Government currently has a draft village regulation draft. The draft village regulation will be discussed later by the Village Government, BPD, and other stakeholders.

Keywords: stunting; design; village regulations.

\section{PENDAHULUAN}

Upaya perbaikan gizi masyarakat sebagaimana disebutkan dalam Undang Undang nomor 36 Tahun 2009 tentang Kesehatan, bertujuan untuk meningkatkan mutu gizi perorangan dan masyarakat, antara lain melalui perbaikan pola konsumsi makanan, perbaikan prilaku sadar gizi, peningkatan akses dan mutu pelayanan gizi serta kesehatan sesuai dengan kemajuan ilmu dan teknologi..

Angka stunting di Nusa Tenggara Barat (NTB) masih terbilang tinggi yaitu sekitar 167 ribu atau 33,49 persen dari 500 ribu balita mengalami stunting. Padahal rata-rata angka stunting nasioanal berkisar 28 persen. (Redaksi Lombok Post, 2020)

Data Riset Kesehatan Dasar (Riskesdas) Kementerian Kesehatan menunjukkan bahwa sejak 2007-2018, angka prevalensi stunting tetap tinggi. Data Riskesdas 2013 menemukan $37,2 \%$ atau sekitar 9 juta anak balita mengalami stunting. Pada 2018, Riskesdas mencatat penurunan prevalensi stunting pada balita ke 30,8\% dan di Kabupaten Lombok Barat tercatat prevalensi stunting sebesar $33.6 \%$. Namun demikian, angka ini masih tergolong tinggi.(Diskominfo Kabupaten Lombok Barat, 2019)

Hasil Riset Kesehatan Dasar Kabupaten Lombok Barat Tahun 2018 untuk balita usia 059 bulan menunjukkan bahwa indeks berat badan menurut umur (BB/U) angka kurang gizi sebesar $29.94 \%$, yang artinya bahwa Kabupaten Lombok Barat berada pada kategori wilayah rawan gizi. Indeks berat badan menurut panjang badan (BB/PB) atau tinggi badan (BB/TB), prevalensi Kekurusan (sangat kurus dan kurus) sebesar $15.04 \%$ yang menunjukkan bahwa Kabupaten Lombok Barat berada pada kategori wilayah rawan. Demikian pula untuk indeks panjang badan atau tinggi badan menurut umur (PB/U atau $T B / U)$, prevalensi kependekkan 33,61\% yang menunjukkan bahwa Lombok Barat merupakan wilayah dengan masalah stunting.(Datin Litbangkes, 2019)

Stunting adalah masalah gizi kronis yang disebabkan oleh asupan gizi yang kurang dalam waktu lama. Hal ini terjadi karena asupan makan yang tidak sesuai dengan kebutuhan gizi. Stunting terjadi mulai dari dalam kandungan dan baru terlihat saat anak berusia dua tahun. Menurut UNICEF, stunting didefinisikan sebagai persentase anak-anak usia 0 sampai 59 bulan, dengan tinggi di bawah minus (stunting sedang dan berat) dan minus tiga (stunting kronis) diukur dari standar pertumbuhan anak keluaran WHO. Stunting diakibatkan oleh banyak faktor, seperti ekonomi keluarga, penyakit atau infeksi yg berkali-kali. Kondisi lingkungan, baik itu polusi udara, air bersih bisa juga mempengaruhi stunting. Tidak jarang pula masalah non kesehatan menjadi akar dari masalah stunting, seperti masalah ekonomi, politik, sosial, budaya, kemiskinan, kurangnya pemberdayaan perempuan, serta masalah degradasi lingkungan.(Humas RSUP Dr Sardjito, 2019)

Penanganan masalah stunting tidak mungkin bisa diselesaikan sendiri oleh sektor kesehatan, oleh sebab itu perlu dukungan seluruh jajaran perangkat daerah dan masyarakat. Seperti yang sudah dilakukan oleh Pemeritah Kabupaten Lombok Barat dengan membuat Peraturan Bupati Lombok Barat No 19.A Tahun 2020 tentang Pencegahan dan Penangan Stunting, diundangkan pada tanggal 17 April 2020 pada Berita Daerah Kabupaten Lombok Barat Tahun 2020 Nomor 19.A.

Dimana, dalam Pasal 10 angka 14 (a) Peraturan Bupati Lombok Barat No 19.A Tahun 2020. menyatakan adanya peran perangkat daerah dalam aksi konvergensi stunting yaitu: Peran Pemerintah Desa ialah menetapkan peraturan desa tentang pencegahan dan penanganan stunting.

Berdasarkan Undang-Undang Nomor 6 Tahun 2014 tentang Desa dalam rangka pelaksanaan otonomi, khususnya di tingkat desa, akan sangat bergantung pada kesiapan 
pemerintah desa dalam menata sistem pemerintahannya agar tercipta pembangunan yang efektif, efesien, transparan, dan akuntabel serta memperoleh partisipasi dari masyarakat desa dalam penyelenggaraan pemerintahannya. (Lelisari, Imawanto, Hamdi, 2020)

Desa Gelogor merupakan salah satu desa dari 10 (sepuluh) Desa yang ada di Kecamatan Kediri, terdiri dari tujuh dusun yaitu dusun Gelogor Pusat, Dusun Gelogor Selatan, Dusun Gelogor Tengah, Dusun Gelogor Timur, Dusun Gersik Selatan, dan Gersik Utara., dengan luas wilayah Desa Gelogor yaitu : 186,162 Ha. Selama perjalanan Pemerintahan Desa Gelogor dari awal berdirinya sampai saat ini sudah 2 (dua) kali berpindah lokasi Kantor Desa yang pertama berlokasi di Dusun Gelogor Selatan pada masih menjadi desa persiapan, yang selanjutnya di pindahkan ke Dusun Gelogor Pusat setelah menjadi desa definitif sampai dengan saat ini. Desa Gelogor merupakan desa pemekaran dari desa induk Rumak yang dimekarkan pada tahun 1998. Pemekaran dilakukan karena melihat perkembangan dan luas wilayah, jumlah penduduk serta aspirasi dari masyarakat diwilayah desa Gelogor yang sudah sesuai dengan tatanan yang berlaku tentang Pemekaran Desa.

Berdasarkan data dan informasi yang diperoleh pada saat kegiatan penyusunan rencana pembangunan janagka menengah desa (RPJMDes) ada berbagai persoalan dan masalah yang dihadapi masyarakat terutama masyarakat miskin dan perempuan. Dari berbagai persoalan dan masalah yang ada dapat dirangkum salah satunya adalah penanganan masalah stunting.

Dalam hal ini Desa Gelogor Kecamatan Kediri Kabupaten Lombok Barat belum juga mempunyai peraturan desa tentang pencegahan dan penanganan stunting sesuai amanat dari Peraturan Bupati Lombok Barat No 19.A Tahun 2020.

Permasalahan yang dihadapi oleh mitra yang menjadi fokus pengabdian tim pengusul adalah pemerintahan desa belum mempunyai peraturan desa tentang pencegahan dan penanganan stunting sesuai dengan amanat dari Peraturan Bupati Lombok Barat No 19.A Tahun 2020. Dimana peraturan desa tersebut sangat penting untuk mencegah dan menangani bahkan mengurangi angka stunting di Kabupaten Lombok Barat.

Adapun solusi yang ditawarkan setelah mengikuti kegiatan sosialisasi ini yaitu: mengerti dan memahami tentang pentingnya mencegah dan menangani stunting dan meningkatkan kesadaran terhadap masyarakat tentang pentingnya mengetahui Peraturan Bupati Lombok Barat No 19.A Tahun 2020 tentang Pencegahan dan Penangan Stunting.

\section{METODE}

Dalam memberikan pemahaman kepada Pemerintah Desa, Badan Perwakilan Desa (BPD) dan masyarakat terkait dengan pendampingan penyusunan rancangan peraturan desa tentang pencegahan dan penanganan stunting di Desa Gelogor Kecamatan Kediri Kabupaten Lombok Barat, Adapun tahapan atau langkah-langkah yang dilakukan dalam pelaksanaan kegiatan tersebut adalah sebagai berikut:

Tahap Persiapan

Pada tahap persiapan, meliputi:

a. Survey ke lokasi untuk mengetahui profil dari desa Gelogor yang menjadi mitra

b. Menyiapkan sarana dan prasarana yang dibutuhkan dalam kegiatan pendampingan dalam menyusun peraturan desa tentang pencegahan dan penangan stunting.

Tahap Pelaksanaan

Pada tahap ini pelaksaaan, meliputi:

a. Melakukan sosialisasi dan penyuluhan hukum mengenai Peraturan Bupati Lombok Barat No 19.A Tahun 2020 tentang Pencegahan dan Penangan Stunting

Metode yang dipergunakan dalam kegiatan ini adalah penyuluhan langsung yaitu kegiatan penyuluhan yang dilaksanakan secara langsung (penyuluh dan yang disuluh bertemu secara langsung), dengan melibatkan masyarakat dan dirancang dalam bentuk ceramah dan Tanya jawab. Sehubungan dengan beragamnya latar belakang masyarakat yang menjadi peserta penyuluhan, maka pendekatan yang digunakan adalah PEKA, yaitu: (Lelisari, Imawanto, 2020)

1) Persuasif artinya bahwa penyuluh (narasumber/fasilitator) dalam melaksanakan tugasnya harus mampu menyakinkan masyarakat yang disuluh, sehingga mereka merasa tertarik terhadap hal-hal yang disampaikan penyuluh.

2) Edukatif artinya penyuluh harus bersikap dan bertingkah dengan penuh kesabaran dan ketekunan membangun/mendampingi masyarakat kearah tujuan yang diinginkan

3) Komunikatif artinya bahwa penyuluh harus mampu berkomunikasi dan menciptakan iklim dan suasana sedemikian rupa sehingga tercipta suatu pembicaraan yang bersifat akrab, terbuka dan timbal balik. 
4) Akomodatif artinya bahwa dengan diajukannnya permasalahan-permasalahan hukum oleh masyarakat, penyuluh harus mampu mengakomodasikan, menampung dan memberikan solusi pemecahan masalah dengan bahasa yang mudah dimengerti dan dipahami oleh masyarakat.

b. Melakukan diskusi/tanya jawab dengan peserta

Diskusi atau tanya jawab dilakukan untuk mengukur sejauh mana pemahaman peserta terhadap Peraturan Bupati Lombok Barat No 19.A Tahun 2020 tentang Pencegahan dan Penangan Stunting. Dimana, dalam Pasal 10 angka 14 (a) Peraturan Bupati Lombok Barat No 19.A Tahun 2020. menyatakan adanya peran perangkat daerah dalam aksi konvergensi stunting yaitu: Peran Pemerintah Desa ialah menetapkan peraturan desa tentang pencegahan dan penanganan stunting.

\section{HASIL DAN PEMBAHASAN}

Dalam kegiatan pendampingan dalam menyusun peraturan desa tentang pencegahan dan penangan stunting ini dilakukan pada hari Jumat, tanggal 5 November 2021 jam 09.30 sampai dengan selesai yang bertempat di aula kantor desa Gelogor Kecamatan Kediri Kabupaten Lombok Barat. Kegiatan ini dihadiri oleh 25 peserta, yaitu Anggota BPD, perwakilan Kepala Dusun, pemerintah desa, kader Posyandu, BKKBN/Penyuluh KB Lombok Barat, remaja, ibu hamil, ibu menyusui dan lain-lain.

Hasil dari kegiatan terbagi dalam dua tahap kegiatan, yaitu tahap persiapan dan tahap pelaksanaan. Pada tahap persiapan bertujuan untuk melihat kondisi sosial dari warga desa Gelogor, baik dari segi pendidikan, pekerjaan dan ekonomi. Selanjutnya dipilih pendekatan sosialisasi yang tepat untuk memberi pengetahuan mengenai Peraturan Bupati Lombok Barat No 19.A Tahun 2020 tentang Pencegahan dan Penangan Stunting. Metode yang digunakan adalah penyuluhan langsung dengan melibatkan masyarakat dan dirancang dalam bentuk ceramah dan tanya jawab.

Pada tahap pelaksanaan, langkah pertama adalah sosialisasi mengenai Peraturan Bupati Lombok Barat No 19.A Tahun 2020 tentang Pencegahan dan Penangan Stunting, dalam Pasal 10 angka 14 (a) Peraturan Bupati Lombok Barat No 19.A Tahun 2020. menyatakan adanya peran perangkat daerah dalam aksi konvergensi stunting yaitu: Peran Pemerintah Desa ialah menetapkan peraturan desa tentang pencegahan dan penanganan stunting. Dimana desa Gelogor sampai saat ini belum menyusun rancangan peraturan desa tersebut. Adapun metode yang digunakan adalah penyuluhan langsung dengan melibatkan masyarakat dan dirancang dalam bentuk ceramah dan tanya jawab. Sehubungan dengan beragamnya latar belakang masyarakat yang menjadi peserta penyuluhan, maka pendekatan yang digunakan adalah PEKA (persuasif, edukatif, komunikatif dan akomodatif). Kemudian acara di buka langsung oleh Kepala Desa Gelogor.

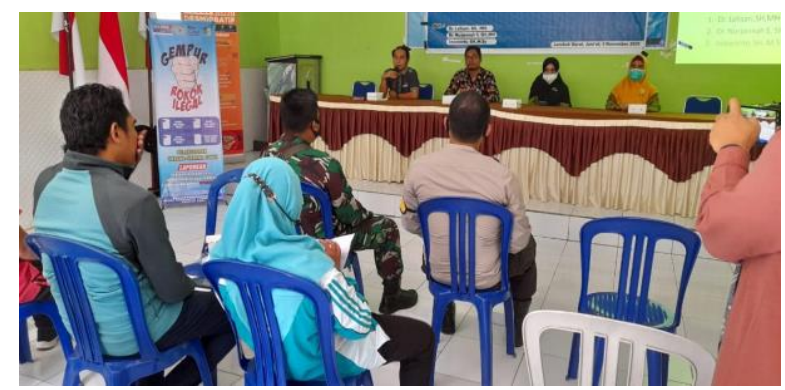

Gambar 1. Pembukaan Acara kegiatan Pendampingan Penyusunan Rancangan Peraturan Desa Tentang Pencegahan dan Penanganan Stunting di Desa Gelogor oleh Kepala Desa

Langkah kedua adalah mendampingi pemerintah desa dalam merancang peraturan desa tentang pencegahan dan penangan stunting. Pada pelaksanaan kegiatan ini masyarakat sangat antusias dan terbantu. Sama halnya dengan anggota BPD dan Pemerintah desa Gelogor. Dimana Pemerintah Desa Gelogor tidak mengeluarkan anggaran/dana lagi untuk mendatangkan ahli hukun dalam penyusunan peraturan desa.

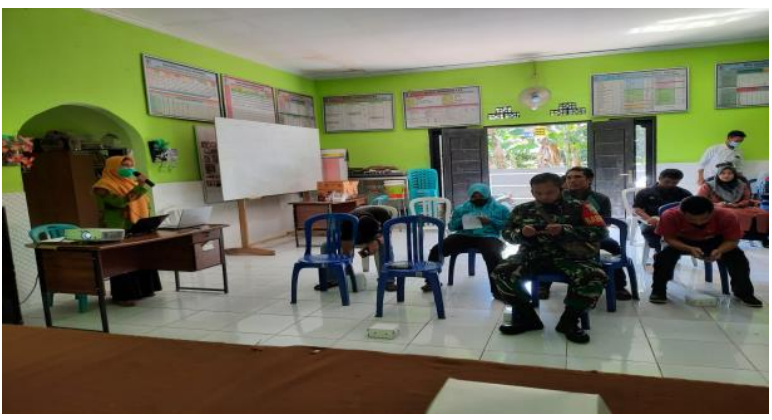

Gambar 2. Proses Pendampingan penyusunan rancangan peraturan desa 


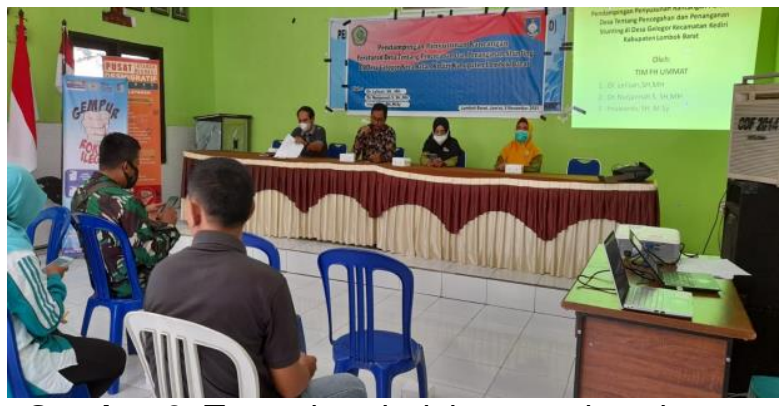

Gambar 3. Tanya jawab dalam pendampingan penyusunan rancangan peraturan desa

Dari proses penyusunan dan perancangan peraturan desa tersebut, dirumuskan materi sebagai berikut:

1) Ketentuan Umum

Dalam ketentuan ini memuat tentang pengertian atau defenisi mengenai desa, pemerintah desa, pemerintahan desa, BPD, kepala desa, peraturan desa, stunting, Intervensi Gizi Spesifik, Intervensi Gizi Sensitif, Upaya perbaikan gizi, Pencegahan dan Penanganan stunting, Tenaga gizi terlatih, Petugas gizi, Posyandu, Air Susu Ibu dan Makanan pendamping Air Susu lbu.

2) Asas-Asas dalam Pencegahan dan Penanganan stunting Asas-Asas Pencegahan dan Penanganan stunting adalah:

a) Bertindak cepat dan akurat

b) Penguatan kelembagaan dan kerjasama

c) Transparansi

d) Peka budaya

e) Akuntabilitas

3) Tujuan pencegahan dan penanganan stunting

Pencegahan dan penanganan stunting bertujuan untuk meningkatkan status gizi masyarakat dan kualitas sumber daya manusia.

4) Ruang Lingkup pencegahan dan penanganan stunting

Ruang lingkup pencegahan dan penanganan stunting berkaitan dengan intervensi gizi spesifik dan intervensi gizi sensitive.

Sasarannya :

(1) Sasaran kegiatan pencegahan dan penanganan stunting, meliputi:
a. Sasaran untuk intervensi gizi spesifik;
b. Sasaran untuk intervensi gizi sensitive.

(2) Sasaran untuk intervensi gizi spesifik sebagaimana dimaksud pada ayat (1) huruf a, meliputi:
a. Remaja putri dan putra;
b. Calon pengantin;
c. Ibu hamil;
d. Ibu menyusui;
e. Ibu menyusui dengan anak di bawah 6 bulan;
f. Ibu dengan anak usia 6-23 bulan;
g. Anak usia 0-5 bulan; dan
h. Anak usia 6-59 bulan.

(3) Sasaran untuk intervensi gizi sensitif sebagaimana dimaksud pada ayat (1) huruf $b$ yaitu masyarakat umum, khususnya keluarga.

5) Cara penanganan stunting

Adapun cara pembinaanya meliputi:

a) Pembinaan dilakukan guna mengatahui upaya apa saja yag telah dilakukan di desa untuk mengatasi stunting ;

b) Pemberian makanan tambahan, pemantauan tumbuh kembang anak secara teratur;

c) Revitalisasi kader posyandu;

d) Serta memberikan penyuluhan tentang cara penanganan dan pencegahan stunting kepada orangtua;

e) Meningkatkan sanitasi lingkungan melalui pembuatan jamban bagi keluarga yang belum memiliki jamban.

6) Pemenuhan ekonomi keluarga penderita stunting

Adapun pemenuhan ekonomi keluarga penderita stunting meliputi:

a) Pendampingan dalam pengelolaan hasil pertanian bagi keluarga penderita stunting;

b) Pemberian bantuan dan pendampingan usaha bagi keluarga penderita stunting.

7) Pembiayaan

Adapun pembiayaan meliputi:

a) Pembiayaan untuk menjalankan kewenangan desa bersumber dari Anggaran Pendapatan dan Belanja Desa;

b) Pemerintah Desa dapat mengembangkan dan memperoleh bagi hasil dari usaha bersama antara pemerintah Desa dengan masyarakat Desa.

\section{SIMPULAN DAN SARAN}

Adapun yang menjadi simpulan dalam kegiatan pendampingan penyusunan rancangan peraturan desa tentang pencegahan dan penanganan stunting adalah kegiatan berjalan dengan lancar dan sesuai dengan jadwal yang dibuat. Pemerintah Desa Gelogor , BPD dan 
jajarannya sangat antusias mengikuti kegiatan tersebut. oleh karenanya Pemerintah Desa Gelogor saat ini sudah mempunyai draf rancangan peraturan desa. Dimana draf rancangan peraturan desa tersebut akan dibahas pada tahap selanjutnya oleh Pemerintah Desa, BPD dan stakeholder lainnya. Adapun saran yang diberikan, perlu kiranya membekali dan memperkuat kembali Pemerintah Desa dan anggota BPD dalam hal penyusunan rancangan peraturan desa.

\section{UCAPAN TERIMAKASIH}

Tim pengabdian kepada masyarakat (PKM) mengucapkan terimakasih kepada Universitas Muhammadiyah Mataram dan LPPM Universitas Muhammadiyah Mataram yang telah mendanai kegiatan pengabdian ini, sehingga rangkaian kegiatan terealisasi. Kemudian Tim pengabdian juga mengucapkan terimakasih kepada Kepala desa Gelogor beserta jajarannya yang telah memberikan sambutan dalam kegiatan pendampingan penyusunan rancangan peraturan desa tentang pencegahan dan penanganan stunting.

\section{DAFTAR RUJUKAN}

Datin Litbangkes. (2019). Pertemuan Rembuk Stunting Tingkat Kabupaten Lombok Barat.

https://dinkes.ntbprov.go.id/berita/pertem uan-rembuk-stunting-tingkat-kabupatenlombok-barat/

Diskominfo Kabupaten Lombok Barat. (2019). Tekan Angka Stunting, Lombok Barat Diintervensi usat.

https://lombokbaratkab.go.id/tekanangka-stunting-lobar-diintervensi-pusat/

Humas RSUP Dr Sardjito. (2019). Kenali Penyebab Stunting Pada Anak. https://sardjito.co.id/2019/07/22/kenalipenyebab-stunting-anak/

Lelisari, Imawanto, Hamdi, A. (2020). Peningkatan Pemahaman Masyarakat Tentang Pengangkatan dan Pemberhentian Perangkat Desa Melalui Sosialisasi Peraturan PerundangUndangan No 6 Tahun 2014. Jurnal Pemberdayaan Masyarakat Berkarakter, 3(2), 199-208. journal-litbangrekarta.co.id

Lelisari, Imawanto, H. (2020). PELINDUNGAN PEKERJA MIGRAN INDONESIA DI DESA BONJERUK. Selaprang, 4(2), 334-339.

http://journal.ummat.ac.id/index.php/jpm b/article/view/4446/2571

Redaksi Lombok Post. (2020). Gawat, 167 Ribu Balita NTB Mengalami Stunting. https://lombokpost.jawapos.com/headlin e/15/02/2020/angka-stunting-di-ntbmasih-tinggi/

Indonesia, Undang Undang Nomor 36 Tahun 2009 tentang Kesehatan

Indonesia, Peraturan Bupati Lombok Barat No 19.A Tahun 2020 tentang Pencegahan dan Penangan Stunting 